\title{
Reducing Food Waste in Hawai'I: How it helps Endangered Species and the Environment?
}

\author{
Matthew* \\ University of Hawaii, USA \\ Submission: February 27, 2018; Published: March 06, 2018 \\ *Corresponding author: Matthew, University of Hawaii, Manoa, USA, Email: loke@hawaii.edu
}

Abstract

This article explores the implications of food waste relating to sanitary landfills, alternate disposal methods, and associated wildlife in the natural environment of a geographically isolated chain of islands. Birds and small animals are attracted to landfills in search of food. In Hawai' $i$, some of these species are invasive and turn predatory to threatened and endangered native avian species. Reducing food waste to curtail feed source available in sanitary landfills can limit the growth of such invasive populations and lessen the threat of extinction to endangered native species. Additionally, the recycling of food waste with new disposal technologies into methane, biofuels, and electricity generation is advantageous since it frees up landfill space, reduce feed to predatory species, and produces value-added products which reduce the carbon footprint with lesser oil imports. All these efforts help protect endangered native avian species, reduces pollution runoffs, and prevents overall degradation of the fragile environment.

Abbreviations: EPA: Environmental Protection Agency; CAP: Center for American Progress

\section{Introduction}

Hawai'i wastes slightly over a billion dollars' worth of edible food annually or the equivalent of 237,000 tonnes from postharvest/packaging and dock unloading to final consumers in the food supply chain [1]. While an estimated 88\% [2] of the edible food supply is shipped in (imported) regularly from the U.S. Mainland and beyond, the reverse or shipping food waste (garbage) out is not a feasible option. Food waste is often mingled with pests, insects, and other invasive species that renders it unsanitary for exports to other landfill jurisdictions. In 2010, the City and County of Honolulu (CCH) attempted to barge garbage out to a landfill in Washington State but the initiative ended abruptly when the U.S. Department of Agriculture revoked the inter-state waste transfer permit following a federal court order $[3,4]$. Without that waste export option, Honolulu officials were forced to divert 18,144 tonnes $(20,000$ tons $)$ of compacted garbage in plastic wrapped bales to the waste to energy facility (H-POWER) for incineration. Ironically, it was the planned expansion of H-POWER and the impending closure in 2012 of the municipal landfill, the Waimanalo Gulch Landfill (WGL) that prompted city officials to pursue the waste shipment initiative. That waste saga prompted an indefinite extension to closure of the municipal landfill, much to the chagrin of neighboring communities.

While food waste directly impacts municipal landfills, its influence extends further beyond mere disposal to include wildlife and the environment. A variety of avian and other species, both prevalent and rare are observed to frequent landfills and adjacent surroundings (hill lands and brush lands). A ridge line running behind Honolulu's municipal landfill, filled with gulches and gullies and stretching south to the Ewa plain is natural habitat to the endangered, Hawaiian owl orpueo (Asio flammeus sandwichensis). It is a sub-species of the short-eared owl and is considered a physical manifestation of the 'aumākua (ancestral guardian spirit) in Hawaiian mythology [5]. Other competing avian species such as the barn owl (Tyto alba) and cattle egret (Bubulcus ibis) also frequent the same geographic location. This article seeks to explore the implications of food waste in relation to sanitary landfills, other disposal methods and associated wildlife and natural environment in a geographic isolated location. The goal of this article is to offer a general assessment of food waste disposal in the short-run and an evaluation of "artificial" feeding on shifting wildlife populations. Pertinent results arising could serve to enhance public awareness, guide policy actions on food waste reduction or to encourage additional research activities on the subject matter [6].

\section{Sanitary Landfills Aand Fauna}

As is seen all over the world, various birds and small animals are attracted to landfills in search of food[6]. One able survey on Oahu documented birds commonly found in and surrounding landfill property to include barred dove (Geopelia maugeus), lace necked dove (Streptopelia chinensis chinensis), cardinal (Cardinalidae), common mynah (Acridotherestristis tristis) and cattle egret [7]. Other small animals found occasionally within 
the site included mongoose (Herpestes javanicus) and feral cat (felis catus). The cattle egret is of particular interest as its growing population is exerting dominance over other species. The cattle egret was intentionally introduced to Hawai'i in the late 1950s to control horn flies (Haematobia irritans L.) on cattle. Unfortunately, no measurable decline in horn fly population was observed but the bird itself expanded in range and population size. Eventually, it became predatory towards native Hawaiian bird species, including preying on the young of the endangered Hawaiian stilt (Himantopus mexicanus knudseni), Hawaiian coot (Fulica alai), Hawaiian gallinule (Gallinula chloropus sandvicensis), Hawaiian duck (Anas wyvilliana), and the Hawaiian owl or pueo. Additionally, the cattle egret forages on wetland invertebrates, competing further with native birds for their food source. Likewise, the barn owl was introduced to Hawai'i as an invasive species to control rodents in sugarcane plantations. The pest control function was not successful but the species thrived and then turned predatory towards other native avian species, including nocturnal seabirds such as the Hawaiian petrel (Pterodroma sandwichensis) and the Hawaiian (Newell's) shearwater (Puffinus newelli).

The predatory practices of both species have become well documented and sufficiently egregious that the U.S. Fish and Wildlife Service has sought to establish a control order to take (without permit) cattle egrets and barn owls so as to protect threatened and endangered native avian species in Hawai'I [8]. The same threats posed by other introduced predators that also visit sanitary landfills such as mongooses and feral cats should not be underestimated. Both these small animals are notorious slayer predators to all the threatened and endangered native avian species mentioned above, particularly their eggs and hatchlings(chicks)across the Hawaiian Islands. Reducing food waste to curtail food source available in sanitary landfills is relatively, a small price to pay for supporting the continuing survival of threatened or endangered native avian species in the entire Hawaiian Island archipelago. Recent sightings of the pueo have been highly infrequent. When detected, they are often injured, victims of vehicle accidents. The pueo birds are often enticed to roadsides by rats and mice, which in turn are lured there by food scraps, tossed out from passing vehicles. A 2018 legislative bill identified the Hunehune gulch and Kaloi gulch (south of WGL) converge as pueo habitat and referenced only 11 remaining pueo living on the island of Oahu [9].

\section{Food Waste and Renewable Energy}

An estimated $38 \%$ of food waste by weight in Hawai'i is generated from a residual classification which include soils and fats, processed food, other grains, sugar and sweeteners, etc., [1]. This "energy" rich grouping of food waste accounted for $62 \%$ of all food waste when measured in calorie equivalent. For this reason alone, disposal of such a food waste group into sanitary landfills may not be optimal as it can be transformed into higher value products with new disposal technologies. The diversion of such food waste is also advantageous as externalities arising from likely soil contamination and leaching can be avoided and simultaneously, averting potential hazards to the environment. The valorization of food waste into energy production is now commercially feasible. Food waste is well documented as a source rich in lipids, carbohydrates and proteins [10]. The food waste could then be subjected to hydrothermal liquefaction and followed by anaerobic digestion to extract the energy [11]. In the hydrothermal liquefaction process, the food waste is pressured cooked to generate a crude bio-oil, which is later refined into biofuel. The remaining food waste is subjected to anaerobic digestion by microbes and thereafter converted into methane. Alternately, the food waste could be incinerated in boilers to generate electricity for commercial use. In Hawai'i, the collection of cooking oils and recycling into liquid, renewable biofuels has been in place for more than 20 years. Across the island chain, a sole commercial recycler now boasts production capacity of 5.5 million gallons of biodiesel annually, most of it sold, reportedly at a lower price to the state leading utility for commercial generation of electricity $[12,13]$. While the carbon footprint may not be exceeding large, it nevertheless offers the "proof of concept" for the commercial feasibility of recycling food waste into biodiesel and generation of electricity. Most commercial power plants in Hawai'i utilizes oil to generate electricity and this effort alone saves the state over 111,000 barrels of imported oil annually .

If Hawai' $i$ is rated as the healthiest and most livable state in the U.S., then the CCH must be its standard bearer. In earnest efforts to protect and preserve its natural environment, particularly the natural landscape (shoreline, valleys, and ridges) and natural resources, $\mathrm{CCH}$ is highly committed to reducing waste stream. Over time, an assortment of waste materials ranging from glass, paper, cardboards, green waste, scrap metals, plastics and food waste is subject to regulations and restrictions for disposal. In reference to food waste, hotels, restaurants, grocery stores, food courts, food manufacturers/processors and hospitals of a certain size are required to recycle their food waste [14]. An increasing number of these entities have invested in bio-digesters to comply with the existing regulatory requirements. The outcome has nevertheless been highly positive. Since inception of the disposal restrictions, the volume of curbside food waste collection declined by $23 \%$ from 47,627 tonnes $(52,500$ tons) to 36,458 tonnes $(40,188$ tons) over a 10-year period between 1996 and 2015 [14]. At Honolulu's $\mathrm{H}$-POWER facility, an average tonne of waste generates $587.5 \mathrm{kWh}$ of electricity [14]. Given a cap price of 16.5 cents per kWh [14], the 36,458 tonnes of curbside food waste collected in 2015generated 10.66 million $\mathrm{kWh}$ of electricity or the equivalent value of $\$ 1.76$ million on an annual basis. Clearly, the food waste deemed only worthy of disposal has been transformed into a resource capable of generating positive economic value. However, this enviable situation facing the $\mathrm{CCH}$ in not costless but rather involves substantial upfront capital investment in technology. This option is not available currently to the neighbor island counties and they must continue to rely on sanitary landfills to manage their food waste generated. 


\section{Landfill Disposal Costs}

From a conventional analysis, food waste generated must be dumped and this activity imposes additional costs on society. The U.S. Environmental Protection Agency (EPA) estimates that food constitutes $20 \%$ of all wastes deposited in municipal landfills [15]. In Hawai'i, a waste steam study conducted on curbside collection pointed to a slightly lower, $15.8 \%$ in Honolulu (CCH)[14].The same measure on neighbor island counties is likely higher since they lack the waste to energy facility and must rely more on sanitary landfills. Across the state, the landfill tipping fee ranges from $\$ 61.73$ a tonne in Kauai County to $\$ 100$ a tonne in the CCH, which in 2010 was sharply higher than the U.S. median price of $\$ 44.09$ a tonne ( $\$ 40$ a ton). By using the food waste generated, county de facto population, and county landfill tipping fees, we were able to estimate the upper limit of landfill cost for wasted by county and across the state. Table 1 shows the estimated annual cost of disposing food loss at landfills in Hawai'i at \$22 million in 2010 when all food waste is dumped into sanitary landfills. In reality, this estimate is much lower since wasted food could alternately be channeled in an assortment of ways - (a) reuse (e.g., recover unused food to feed people in need or swill to feed animals), (b) recycle (e.g., composting, and bio-digesting) and (c) disposal (e.g., incinerating and kitchen sink erator).A more precise metric on the proportion of food waste disposed via each method is not readily available in the existing literature. Beyond this landfill cost, there are other costs (negative externalities) which are more difficult to measure but may have impacts on overall degradation of the environment. Trash collection and hauling services have not been considered. Odor, particulate emissions, human health impacts and land area depletion are important considerations. Another cost is the decomposition of food waste in the landfills into methane, a potent greenhouse gas that contributes much more to climate change and rising sea level, relative to carbon dioxide. Finally, leaching landfills may cause pollution runoffs during rainy seasons and discharging contaminantsor toxins directly into the ocean; threatening public health at popular beaches and damaging fragilecoral reefs.

Table 1: Upper limit estimate of landfill cost for wasted food by county, 2010

\begin{tabular}{|c|c|c|c|}
\hline County & Cost (\$/tonne)* & Weight (tonne) & $\begin{array}{c}\text { Total Cost } \\
\text { mil.) }\end{array}$ \\
\hline C\&C Honolulu & 100.00 & $159,446.2$ & 15.9 \\
\hline Hawai'i & 93.70 & $32,706.3$ & 3.1 \\
\hline Kauai & 61.73 & $13,478.4$ & 0.8 \\
\hline Maui & 69.45 & $31,369.0$ & 2.2 \\
\hline Statewide & - & $237,000.0$ & 22.0 \\
\hline
\end{tabular}

*Includes disposal surcharge.

Sources: DBEDT 2013 [16] and DOH 2012 [17].

\section{Economic Efficacy of Food Waste}

International policy makers, food activists, and academicians have advocated the reduction of food waste as a leading priority to improving the efficiency of resource utilization, increasing food security, and reducing degradation of the global environment. Additionally, it is morally unethical to waste food when so many people are facing hunger and food insecurity. Many policy recommendations have since been made and policy targets established (e.g., reduce disposal of edible food waste by $50 \%$ by 2020 and reduce greenhouse gas emissions to 1990 levels by 2020). While food waste is a problem of global significance, we are more focused here on a small, isolated economy, which is dependent largely on food imports to feed ourselves. Affordability is clearly an ongoing concern to local consumers as the state collectively spends an estimated $\$ 4.5$ billion annually on food [2]. Limited landfills also impose additional burdens of costs and hazard impacts to our fragile environment. The primary intervening channel in reducing food waste in Hawai'i is in the food supply chain; where as food waste diversion deals with cost reduction and environment impacts of sanitary landfills $[16,17]$.

\section{Discussion}

Reducing food waste in Hawai'i is arguably a commendable social practice and policies directed at recycling and diverting it from sanitary landfills appears advantageous from a wildlife and environmental preservation perspective. All over the world, we have seen food waste dumped at sanitary landfills increasingly becoming an artificial source of food for many birds, small animals, and insect species. In Hawai'i, more available food enables these species to expand their population base, and for predatory ones to threaten the very existence of endangered native avian species. This is particularly disconcerting to Hawai'i as it hosts a rich biodiversity, including a high proportion of endemic fauna and flora species. Hawai'i has been called the "endangered species capital of the world" as more than $25 \%$ of all species found on the U.S. endangered species list are endemic to Hawai'i [18]. While it may appear that an increasing volume of food waste benefits non-native species much more than native species, the perceived bias is unintended. Rather, it may be better explained as a function of predation as opposed to direct competition. Nonnative species (particularly avian) appear more readily to feed off food sourced from landfills as compared to native species. The latter cohort has a higher propensity to consume endemic insects and small invertebrates. This position is supported by findings in a recent published article on coqui frogs (Eleutherodactylus coqui) and bird populations in Hawai'i [19]. The article's authors hypothesized that invasive coquis would compete for food and to weaken the population of native birds. Instead, they discovered that non-native bird species grew in abundance by feeding on coquis as a novel food source.

Computed from Liquid Fuel Measurements and Conversions published by the lowa State University Extension. Available from https://www. extension.iastate.edu/agdm/wholefarm/pdf/c6-87.pdf 


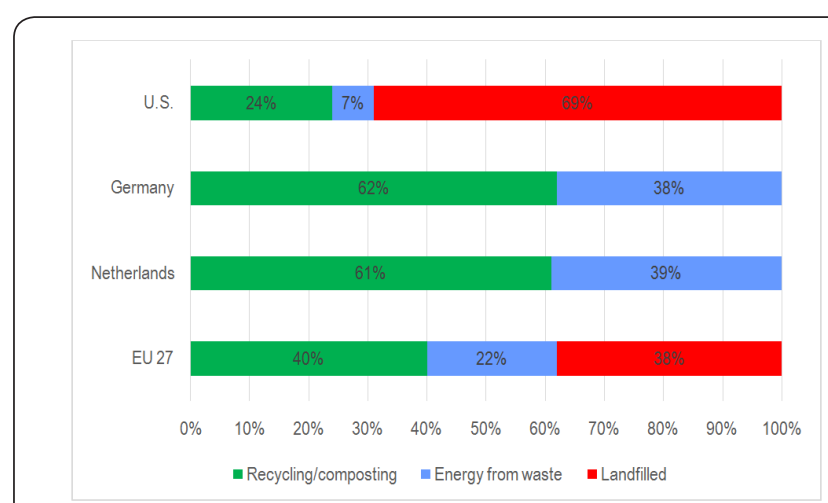

Figure 1: Waste by different disposal methods in the U.S. and Europe.

Source: Center for American Progress (CAP).

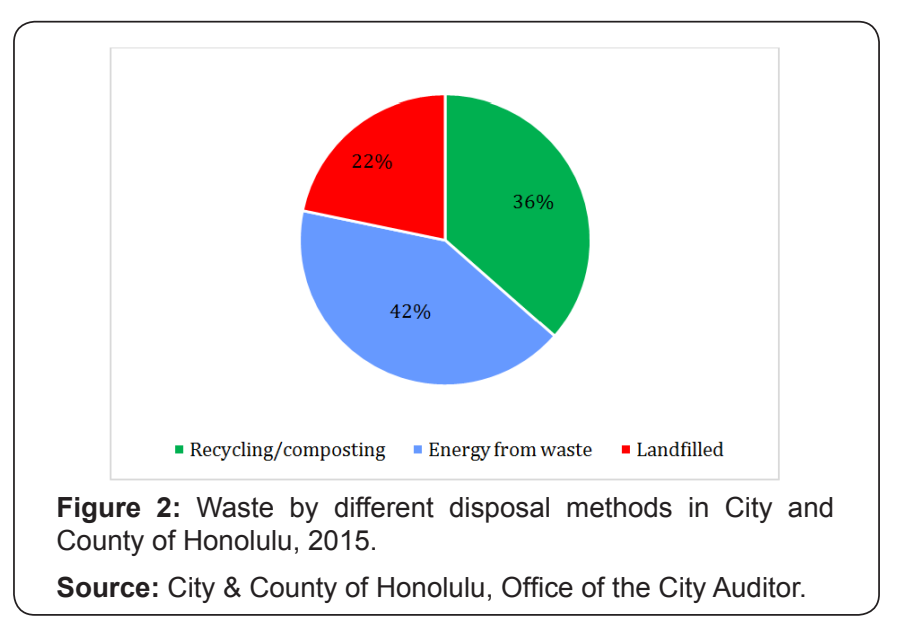

Withoutreservations, any effortsto curtail food source available in sanitary landfills to predatory species is an excellent strategy to preserve the existence of threatened and endangered species in Hawai'i. The ultimate goal is to divest all food waste streams flowing into sanitary landfills. This outcome is totally viable but for different reasons, the U.S. finds itself behind the progress curve in diverting food waste streams from landfills. European countries have lead the world in this initiative by recycling/composting and generating energy from waste streams. Germany and the Netherlands have completely divested themselves from utilizing sanitary landfills as a method to dispose waste (trash). Figure 1 shows the comparative management of waste by different disposal methods in the U.S. and Europe [20].Clearly, some $69 \%$ of waste in the U.S. is handled via landfills, $24 \%$ recycled or composted, and $7 \%$ converted into energy. In Germany, $62 \%$ of waste is recycled or composted, and the remaining 38\% converted into energy. The European Union, with its 27 members, collectively handled 38\% of its waste via landfills, $40 \%$ recycled or composted, and $22 \%$ converted into energy. In Hawai'i, statewide data are sketchy at best but $\mathrm{CCH}$ data is more revealing. Data weaved from the $\mathrm{CCH}$ Office of the Auditor suggests that some $22 \%$ of waste in Honolulu is handled via landfills, $36 \%$ recycled or composted, and $42 \%$ converted into energy (Figure 2). These statistics are promising, putting Honolulu ahead of the U.S. and catching up with the EU
27. And even more impressive is revelation that $76 \%$ of the solid waste going into the municipal landfill (WGL) is ash and residue from the H-POWER waste to energy facility. Unfortunately, waste disposal methods on the neighbor islands lag behind the $\mathrm{CCH}$ as they currently have no capacity to convert waste into energy. The primary disposal method remains the sanitary landfill, although efforts are being made to adopt more recycling and composting.

As more and more trash (including food waste) is recycled/ composed and incinerated to generate electricity, a lesser amount is deposited into sanitary landfills, therefore decreasing the food source to birds, small animals, rodents, and insects that frequent and forage the disposed materials. This outcome lessens the risks associated with growing populations of predatory species and adverse environmental effects relating to landfill operations. With growing populations in neighbor island counties, it is clear that more recycling and composting efforts are needed there to divest waste streams from flowing into sanitary landfills. Unlike the urban $\mathrm{CCH}$, the neighbor island counties are anchored in a rural setting and arguably host disproportionately more habitats to Hawai'i's threatened and endangered species. One alternate option is to enact regulatory reforms so as to facilitate the shipment of waste from neighbor islands to Honolulu for disposal at the H-POWER facility. Another option is to invest in waste to energy technology similar to H-POWER. Likewise, additional research to better measure the amount of food waste channeled into various disposal methods will support improved management policy and strategic decision making.

\section{Conclusion}

Reducing food waste is a concept that is often overlooked in Hawai'i. The implications of food waste and its effects on the fragile environment and endangered native avian species are even less evident, if at all noticeable. When food waste is disposed together with other solid waste in landfills, it often turns into an "artificial" feeding ground for predatory birds, small animals, and insects, which target threatened and endangered native avian species. Additionally, over time, the organic food waste when land filled decomposes into methane, a potent greenhouse gas. Each tonne of food waste is estimated to generate two tonnes of carbon dioxide equivalents [21]. With new commercial technologies, the valorization of food waste into energy production is feasible. Food waste as a zero-value resource is now recyclable into products of higher commercially value such as biodiesel, methane (via anaerobic digestion) and electricity. In anticipation of rising population pressures, neighbor island counties in Hawai'I will have to consider various options to divert food waste and trash in general, away from their aging sanitary landfills. Such a policy goal is crucial to protecting the existence of threatened and endangered native avian species in rural areas. A lower waste intake rate also lessens the risks associated with soil contamination, leaching, pollution run-offs, and further extends the lifespan of the landfills, mitigating costly closure and replacement expenses to taxpayers. Finally, the food waste reduction hierarchy is best administered as follows: (a) reuse (e.g., recover unused food to feed people 
in need or swill to feed animals), (b) recycle (e.g., composting, hydrothermal liquefaction, and anaerobic digestion) and (c) disposal (e.g., incineration, sanitary landfill, and kitchen sink erator). Additional research to support measurements of these food waste channels are also beneficial.

\section{References}

1. Loke MK, Leung PS (2015) Quantifying food waste in Hawaii''s food supply chain. Waste Management \& Research 33(12): 1076-1083.

2. Loke MK, Leung PS (2013) Hawai'i's food consumption and supply sources: Benchmark estimates and measurement issues. Agric Food Econ 1: 10.

3. Cooper M (2010) Ready to ship in Hawai'i: 20,000 tons of garbage. New York Times, USA.

4. Sample HA (2010) Honolulu's long-standing trash woes growing worse. Associated Press, USA.

5. Fish US, Wildlife Service (2017) Hakalau Forest, National Wildlife Refuge, Hawai'i-Pueo.

6. Hanson H (2016) Birds are becoming totally dependent on our delicious landfills. Huffington Post.

7. City and County of Honolulu Department of Environmental Services. Environmental impact statement preparation notice for the Waimanalo gulch sanitary landfill expansion, Honolulu, Hawai'i.

8. US Fish and Wildlife Service (2017) Migratory bird permits; control order for introduced migratory bird species in Hawai'i. Federal Register.

9. (2018) Relating to the habitat conservation preserve of 2018, HB2629, $2^{\text {th }}$ Legislature, Hawaii, US

10. Karmee SK, Lin CSK (2014) Valorisation of food waste to biofuel: current trends and technology challenges. Sustainable Chem Process $2: 22$.

This work is licensed under Creative Commons Attribution 4.0 License DOI: $10.19080 / J O J N H C .2018 .06 .555691$
11. Posmanik R (2017) Coupling hydrothermal liquefaction and anaerobic digestion for energy valorization from model biomass feedstocks. Bioresource Technology 233:134-143.

12. Pacific Biodiesel (2017) Haiwaii military Biofuel crop project.

13. Gomes A (2017) Pacific Biodiesel to supply HECO for another 3 years. Honolulu Star Advertiser.

14. City and County of Honolulu (2017) Office of the City Auditor. Audit of the city's recycling program, Honolulu, Hawai'i.

15. Gerlock G (2014) To end food waste, change needs to begin at home. The Salt, NPR.

16. DBEDT (2013) Hawai'i economic issues: data report 2013, county social, business and economic trends in Hawai'i: 1990-2011. Research and Economic Analysis Division, Hawai'i Department of Business, Economic Development and Tourism (DBEDT), Honolulu, Hawai'i.

17. DOH (2012) Annual report on solid waste management-report to Hawai'i state legislature 2013. Office of Solid Waste Management, Hawai'i Department of Health (DOH), Honolulu, Hawai'i.

18. Green (2013) Hawaii is 'the endangered species capital of the world. Huffington Post, Hawai' i.

19. Smith RL, Beard KH, Koons DN (2017) Invasive coqui frogs are associated with greater abundances of nonnative birds in Hawaii, USA. The Condor: Ornithological Applications.

20. Lacey S (2013) Look at how much waste America puts into landfills compared to Europe. Green Tech Media.

21. European Commission (2010) Preparatory study on food waste across EU-27. Technical Report-2010-054.

\section{Your next submission with Juniper Publishers will reach you the below assets}

- Quality Editorial service

- Swift Peer Review

- Reprints availability

- E-prints Service

- Manuscript Podcast for convenient understanding

- Global attainment for your research

- Manuscript accessibility in different formats ( Pdf, E-pub, Full Text, Audio)

- Unceasing customer service

Track the below URL for one-step submission https://juniperpublishers.com/online-submission.php 